\title{
Drought Planning for Vegetable Production
}

\section{U}

nder drought conditions, when water may be in short supply, growers often need to estimate the potential water use of their crops to determine how much land can be irrigated. It is also necessary to estimate crop water requirements when buying or leasing land to determine whether a potential water supply is sufficient to fully irrigate a range of potential crops. This publication details the calculations involved in estimating crop water requirements and determining how much land can be irrigated under limited water supplies. Example calculations are provided, as well as a discussion of the key considerations in developing accurate estimates.

\section{Defining Crop Water Needs}

The volume of irrigation water needed to produce a crop is the difference between crop water needs and contributions of water from nonirrigation sources such as precipitation from rain and fog. Other nonirrigation sources of water include moisture contributed by shallow water tables and moisture stored in the soil profile. Water is needed for crop production both preseason (before planting) and in-season. Water may be needed preseason for preparing soil for planting and leaching salts, and during the season for evapotranspiration and controlling salinity, as well as to compensate for inefficiencies in the irrigation application. In some cases water is needed during the season for frost protection or for increasing humidity and lowering the air temperature during hot periods. Each component of in-season and preseason crop water needs must be estimated to determine the overall water needs of a vegetable crop.

\section{Estimating In-Season Water Needs}

\section{Crop Evapotranspiration}

Evapotranspiration (ET) is the water lost from fields by evaporation from the soil and through plant transpiration. Plants transpire water through stomates-small openings on leaves-that allow gas exchange with the atmosphere. The daily ET rate, usually expressed in inches or millimeters per day, depends on weather and crop factors. 
Table 1. Estimated ET of selected vegetable crops and growing regions in California

\begin{tabular}{|l|l|l|c|}
\hline \multicolumn{5}{c}{ Central Coast (interior valleys) } \\
\hline Crop & Irrigation method & Season & ET requirement \\
\hline bok choy (greenhouse) & sprinkler & July-September & inches \\
\hline broccoli & sprinkler & April-June & 4 \\
\hline broccoli & sprinkler & May-July & 13 \\
\hline broccoli & sprinkler & September-March & 14 \\
\hline cabbage & sprinkler & April-August & 6 \\
\hline cauliflower & sprinkler & March-June & 15 \\
\hline cauliflower & sprinkler & November-April & 13 \\
\hline celery & sprinkler/drip* & May-August & 12 \\
\hline lettuce (iceberg) & sprinkler/drip & April-July & 14 \\
\hline lettuce (iceberg) & sprinkler/drip & June-August & 10 \\
\hline lettuce (iceberg) & sprinkler & June-August & 8 \\
\hline peppers (red bell) & drip & May-September & 9 \\
\hline spinach (baby) & sprinkler & May-September & 14 \\
\hline tomato (fresh market) & drip & June-September & 16 \\
\hline tomato (processing) & sprinkler/drip & May-September & 18 \\
\hline & & & 4 \\
\hline
\end{tabular}

\begin{tabular}{|l|l|l|c|}
\hline \multicolumn{5}{c}{ Central Coast (coastal valleys) } \\
\hline Crop & Irrigation method & Season & ET requirement \\
\hline broccoli & sprinkler & March-August & inches \\
\hline broccoli & sprinkler & May-September & 11 \\
\hline broccoli & sprinkler & September-March & 6 \\
\hline brussels sprout & sprinkler & July-December & 14 \\
\hline cabbage & sprinkler & August-October & 10 \\
\hline cabbage & sprinkler & April-July & 11 \\
\hline cauliflower & sprinkler & March-June & 7 \\
\hline cauliflower & sprinkler & August-December & 6 \\
\hline celery & sprinkler/drip* & May-September & 8 \\
\hline lettuce (iceberg) & sprinkler/drip & February-May & 5 \\
\hline lettuce (iceberg) & sprinkler/drip & April-July & 7 \\
\hline lettuce (iceberg) & sprinkler/drip & June-August & 6 \\
\hline
\end{tabular}

\begin{tabular}{|l|l|l|c|}
\hline \multicolumn{2}{|c|}{ South San Joaquin Valley } \\
\hline Crop & Irrigation method & Season & ET requirement \\
\hline & & & inches \\
\hline broccoli & sprinkler & August-November & 11 \\
\hline cantaloupe & sprinkler/drip* & April-July & 13 \\
\hline $\begin{array}{l}\text { onion (fresh-market } \\
\text { bulb) }\end{array}$ & sprinkler/drip & March-September & 27 \\
\hline tomato (fresh market) & drip & May-August & 21 \\
\hline tomato (processing) & sprinkler/drip & March-July & 22 \\
\hline tomato (processing) & sprinkler/drip & May-August & 26 \\
\hline
\end{tabular}

\begin{tabular}{|l|l|l|c|}
\hline \multicolumn{2}{|c|}{ Sacramento Valley } \\
\hline Crop & Irrigation method & Season & ET requirement \\
\hline & & & inches \\
\hline pepper (red bell) & drip & May-September & 22 \\
\hline tomato (processing) & drip & May-September & 23 \\
\hline
\end{tabular}

*Irrigated with sprinklers for stand establishment, followed by drip. 
The amount of water a crop uses for evapotranspiration when it is fully irrigated is called potential ET; the term crop ET is synonymous with potential ET in fully irrigated fields. Yields of vegetable crops are usually maximized when moisture is sufficient to meet the potential ET rate throughout the season. A crop is under water stress when the supply of soil moisture is insufficient to meet potential ET requirements. Short periods of water stress may reduce the growth rate of crops. Prolonged periods of water stress cause the stomates to close to prevent water losses. The closure of stomates reduces the rate of photosynthesis. Consequently, prolonged water stress causes yield losses, especially if water stress occurs during critical periods of crop development, such as flowering or fruit development. Under water stress, crop ET will be less than potential ET.

Potential crop ET depends on where and when a crop is grown, as well as on crop type. Reference ET values are available for most agricultural regions of the state on the website of the California Irrigation Management Information System (CIMIS), an entity managed by the California Department of Water Resources. Reference ET values are derived from weather stations positioned

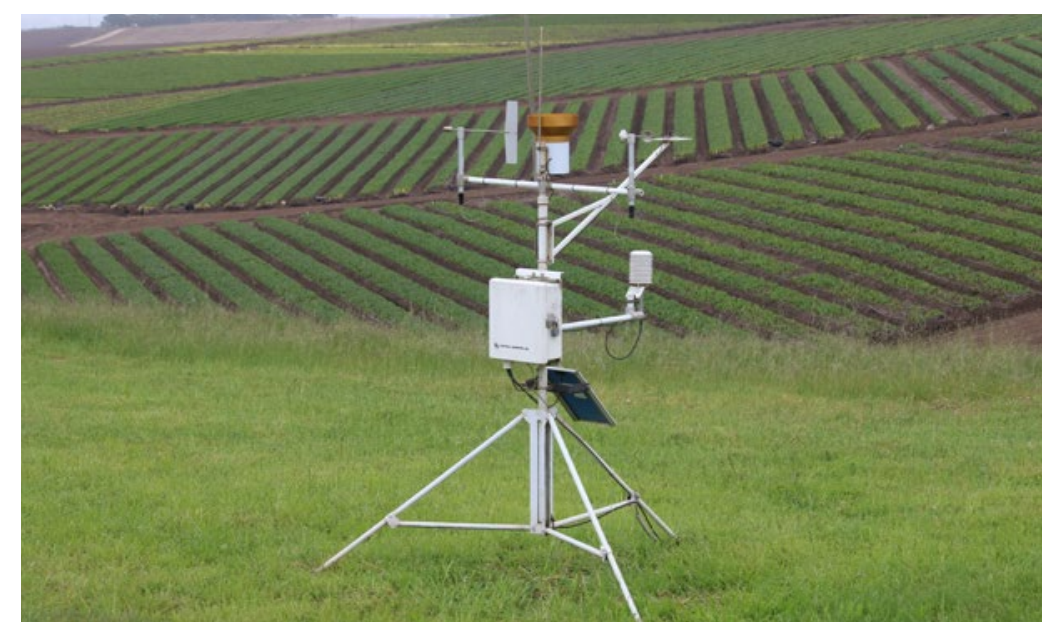

Figure 1. Weather station used to estimate reference evapotranspiration. over a standard reference ground cover (fig. 1), usually grass or alfalfa, with a consistent and full cover of vegetation. Historical daily reference ET values are available for each region, as are historical monthly averages of ET. The reference ET values must be converted using crop coefficients to estimate ET for different crops. Hanson et al. (2004) explain how to estimate crop ET using crop coefficients. Wateright, Irrigation Scheduler Mobile, and CropManage are examples of online applications that can be used to estimate ET of vegetable crops on the basis of CIMIS reference ET data. Table 1 summarizes crop ET values for a range of vegetables produced on the Central Coast and in the Central Valley of California. These values can be used as approximations for ET requirements for these regions.

\section{Irrigation Efficiency}

Irrigation efficiency needs to be factored into the irrigation requirement of a crop. Irrigation efficiency is defined as the fraction of applied water that remains in the root zone, where it can be used by the crop. A portion of applied water may be lost to drainage or runoff. Both the distribution uniformity (DU) of an irrigation system and scheduling of irrigations can affect irrigation efficiency. Assuming that the irrigation schedule is optimized by good management, DU may be considered a close approximation of irrigation efficiency. A high DU means that an irrigation system applies water uniformly in a field. Most drip systems, if designed and operated well, have a DU greater than 85 percent. Sprinkler systems, if maintained and operated well, have DU values ranging from 70 to 80 percent. During the establishment of vegetable crops, growers often apply additional water to compensate for low irrigation efficiency, thus assuring that they attain a uniform stand of plants. Hence it may be advisable to distinguish irrigation efficiency during establishment from irrigation efficiency after establishment.

\section{Salt Management}

Leaching, needed to control salinity in the root zone, increases the water needs of a crop. Cahn and Bali $(2015,8)$ describe how to estimate the leaching requirements (LR) of vegetable crops for specific water and soil salinity conditions. Leaching can be 
accomplished both preseason and during the cropping season, depending on water availability and quality.

The following equation can be used to estimate applied water needed to meet in-season crop water requirements:

$$
\mathrm{AW}=[\mathrm{ETC} \times 100 \% \div \mathrm{DU}] \div[1 \neg-(\mathrm{LR} \div 100 \%)]
$$

where AW is applied water in inches, ETc is crop evapotranspiration in inches, DU is percent distribution uniformity, and LR is leaching requirement expressed as a percentage.

Example: What are the in-season water requirements of summer lettuce irrigated with sprinklers and grown in the interior valleys of the Central Coast if the average DU is 70 percent and the LR needed is 10 percent?

According to table 1, sprinkler-irrigated lettuce planted in June needs 9 inches of water for ET. Using the above equation, 14.3 inches of applied water are needed to grow a lettuce crop.

$$
\begin{gathered}
A W=9 \text { inches } \times 100 \% \div 70 \% \div[1-(10 \% \div 100 \%)] \\
A W=14.3 \text { inches }
\end{gathered}
$$

\section{Crop Establishment Water}

To assure that a crop begins with a uniform stand of plants, vegetables often require significantly more water than crop ET during the seed germination phase or during transplant establishment (fig. 2). The amount of water necessary for establishment will depend on the existing moisture in the soil, length of time needed for germination or transplant establishment, application efficiency, and weather conditions. In practice, most growers who plant vegetables or establish vegetable transplants in moist soil will apply at least twice the daily reference ET, multiplied by the number of days needed for germination or transplant establishment.

Example: What is the minimum AW needed for germinating a lettuce crop if average reference ET is 0.17 inches per day and seed germination is 7 days?

AW for germination $=2 \times 0.17$ inches $/$ day $\times 7$ days $=2.4$ inches
Frost Protection, Humidity, and Temperature Control

Irrigation is sometimes needed to influence the microclimate of a crop for short periods. Irrigation water applied with sprinklers can protect a crop from frost damage that may occur during cold nights; increase humidity when hot, dry winds blow; or decrease damage from excessively hot conditions. It may be difficult to anticipate the amount of water needed to affect the microclimate of a crop, but past experience and weather records may provide a rough guide.

\section{Estimating Preseason Water Needs}

Calculations for crop water requirements must take into account water applied before planting. An application of preseason water may be needed to bring the soil to field capacity before planting or to facilitate tillage operations. If preseason rainfall was insufficient, additional water may be needed to leach salts that have accumulated in the soil. Often, preseason water application can be minimized by

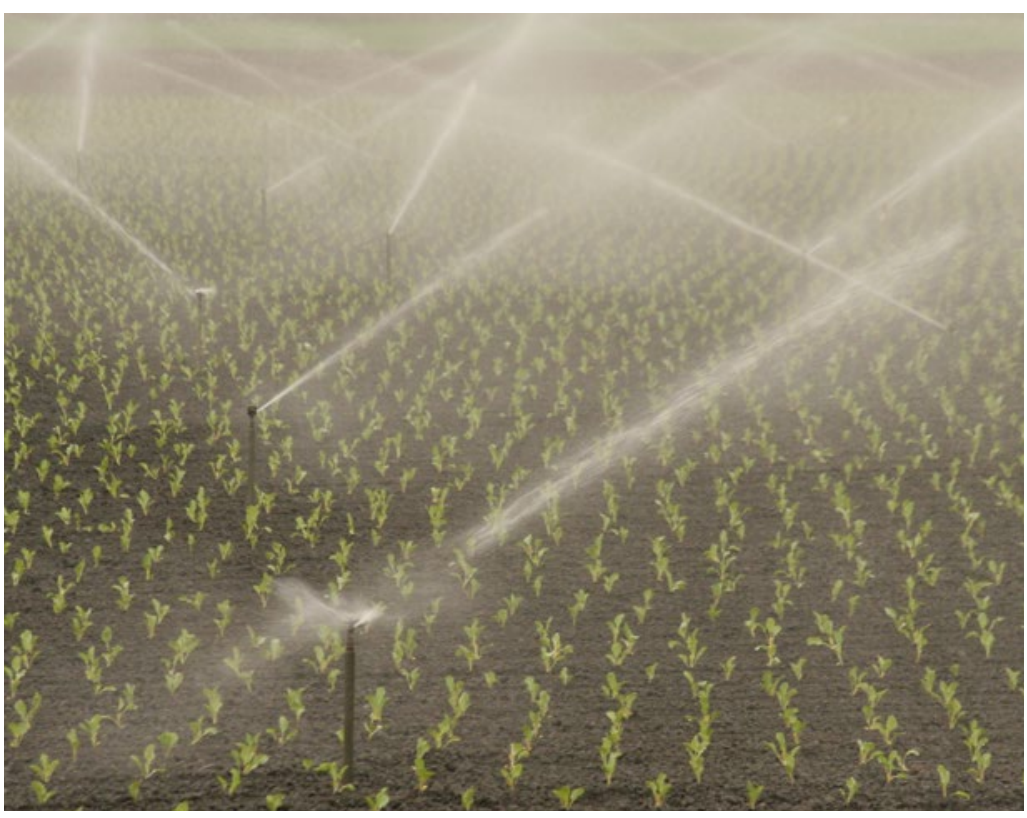

Figure 2. Overhead sprinklers are used to irrigate recently transplanted vegetables. 
evaluating soil water status and determining the amount of water needed to bring the soil to saturation. The required amount of preseason water can be estimated by comparing the current water content of the soil with the water content at field capacity. Table 2 estimates the water content for soil of a range of textures at field capacity (that is, with a tension of about 30 centibars, or cbars).

Example: If the water content of a clay loam soil averages 25 percent to a 2 -foot depth, how much water will be needed to bring the soil profile to field capacity?

Table 2 shows that the water content of a clay loam soil at field capacity is 32 percent, or 0.32 inches per inch of soil depth. The amount of water needed to bring the soil to field capacity equals:

\section{$(0.32-0.25) \times 2 \mathrm{ft} \times 12$ inches $/ \mathrm{ft}=1.7$ inches}

\section{Estimating Nonirrigation Sources of Water}

Nonirrigation sources of water can satisfy a portion of crop water needs. These sources include water from rainfall, fog, and shallow water tables. Moisture stored in the soil profile can also provide a portion of the water needed to produce a vegetable crop.

\section{Soil Moisture Contribution to Crop Water Requirements}

Even during a drought, a significant portion of the moisture contributing to crop ET may be stored in the soil after preseason rains or after preseason irrigations. Soil moisture contributing to crop water use is the difference between soil water content at time of planting and time of harvest.

Soil moisture available for a crop can be estimated from the water-holding characteristics of a soil. A soil's water-holding characteristics describe the amount of water a soil can hold and how tightly water is held at different water contents. Soils with a high percentage of clay- and silt-sized particles (clay, clay loam) hold more water than soils with a high percentage of sand (sand, sandy loam). Moisture in fine-textured soil, such as clay loam, is held tighter than in coarse-textured soil such as sandy loam. A portion of the water held in the pores of a soil is available to a crop and the remainder is unavailable because it is held too tightly for crop roots
Table 2. Typical water holding capacity of soils of different textures

\begin{tabular}{|l|l|l|l|}
\multicolumn{1}{|c|}{ Soil texture } & \multicolumn{1}{|c|}{$\begin{array}{c}\text { Field capacity } \\
\text { (30 cbars) }\end{array}$} & $\begin{array}{c}\text { Wilting point } \\
\text { (1,500 cbars) }\end{array}$ & \multicolumn{1}{c|}{$\begin{array}{c}\text { Available } \\
\text { moisture }\end{array}$} \\
\hline sand & 0.10 & 0.04 & \\
\hline loamy sand & 0.16 & 0.07 & 0.06 \\
\hline sandy loam & 0.21 & 0.09 & 0.09 \\
\hline loam & 0.27 & 0.12 & 0.12 \\
\hline silt loam & 0.30 & 0.15 & 0.15 \\
\hline sandy clay loam & 0.29 & 0.18 & 0.15 \\
\hline sandy clay & 0.28 & 0.15 & 0.11 \\
\hline clay loam & 0.32 & 0.18 & 0.13 \\
\hline silty clay loam & 0.36 & 0.20 & 0.14 \\
\hline silty clay & 0.40 & 0.20 & 0.16 \\
\hline clay & 0.40 & 0.22 & 0.20 \\
\hline
\end{tabular}

Source: Hanson et al. 2004, 202.

to extract it. Generally, 15 bars is used as a standard tension at which most plants cannot extract water from soil pores. Available water is the difference between the water content of the soil at field capacity (the water content of a soil after it is saturated and excess water drains) and the water content at wilting point. Table 2 provides estimates of available water for soils of a range of textures.

Allowable depletion is the percentage of available soil water that can be taken up by a crop before the soil water content is so low that production and yield are adversely affected. Table 3 summarizes allowable depletions for common vegetable crops. The change in available soil moisture over a crop cycle can be estimated by multiplying the available water of the soil type (table 2 ) by the percentage of allowable depletion (table 3). Rooting depth at harvest (fig. 3) also needs to be considered in the estimate because a deep and extensive root system can extract more soil moisture than can a shallow, less developed root system. Table 4 summarizes common rooting depths of vegetable crops. 


\section{Table 3. Allowable depletion of available soil moisture at crop maturity}

\begin{tabular}{|c|c|}
\hline Crop & $\begin{array}{c}\text { Allowable } \\
\text { depletion of } \\
\text { available soil } \\
\text { moisture }\end{array}$ \\
\hline & $\%$ \\
\hline artichoke & 45 \\
\hline asparagus & 40 \\
\hline bean (green) & 30 \\
\hline bean (snap) & 30 \\
\hline beet (table) & 50 \\
\hline broccoli & 40 \\
\hline brussels sprout & 50 \\
\hline cabbage & 35 \\
\hline cantaloupe & 40 \\
\hline carrot & 35 \\
\hline cauliflower & 40 \\
\hline celery & 25 \\
\hline chard & 30 \\
\hline cilantro (coriander) & 30 \\
\hline corn (sweet) & 30 \\
\hline cucumber & 50 \\
\hline eggplant & 30 \\
\hline garlic & 50 \\
\hline kale & 50 \\
\hline leek & 35 \\
\hline lettuce (baby) & 25 \\
\hline lettuce (iceberg) & 30 \\
\hline
\end{tabular}

\begin{tabular}{|l|c|}
\hline Crop & $\begin{array}{c}\text { Allowable } \\
\text { depletion of } \\
\text { available soil } \\
\text { moisture }\end{array}$ \\
\hline lettuce (leaf) & $\%$ \\
\hline lettuce (romaine) & 25 \\
\hline melon (mixed) & 30 \\
\hline okra & 60 \\
\hline onion (dry) & 65 \\
\hline onion (green) & 40 \\
\hline parsnip & 25 \\
\hline pea & 40 \\
\hline pepper (bell) & 30 \\
\hline potato & 25 \\
\hline potato (sweet) & 35 \\
\hline pumpkin & 65 \\
\hline radish & 50 \\
\hline spinach & 35 \\
\hline spinach (baby and & 35 \\
\hline teen) & 25 \\
\hline squash (summer) & 35 \\
\hline squash (winter) & 60 \\
\hline tomato (fresh) & 35 \\
\hline tomato (processing) & 60 \\
\hline turnip (white) & 35 \\
\hline watermelon & 40 \\
\hline
\end{tabular}

Sources: Shock et al. 2007; Hanson et al. 2004, 202; personal communication by growers, consultants, and farm advisors with M. Cahn.

\section{Table 4. Range of rooting depths of common vegetables at maturity}

\begin{tabular}{|c|c|c|c|}
\hline Crop & $\begin{array}{l}\text { Rooting depth at } \\
\text { maturity }\end{array}$ & Crop & $\begin{array}{l}\text { Rooting depth at } \\
\text { maturity }\end{array}$ \\
\hline & feet & & feet \\
\hline artichoke & $2.0-3.0$ & lettuce (leaf) & $1.0-1.5$ \\
\hline asparagus & $2.5-3.5$ & lettuce (romaine) & $1.5-2.0$ \\
\hline bean (green) & $1.5-2.0$ & melon (mixed) & $2.0-4.0$ \\
\hline bean (snap) & $1.5-2.0$ & okra & $2.0-3.0$ \\
\hline beet (table) & $1.0-1.5$ & onion (dry) & $1.5-2.0$ \\
\hline broccoli & $2.0-3.0$ & onion (green) & $1.0-1.5$ \\
\hline brussels sprout & $2.0-3.0$ & parsnip & $2.0-3.0$ \\
\hline cabbage & $2.0-3.0$ & pea & $1.5-2.0$ \\
\hline cantaloupe & $2.0-4.0$ & pepper (bell) & $2.0-3.0$ \\
\hline carrot & $1.5-2.0$ & potato & $1.5-2.0$ \\
\hline cauliflower & $2.0-3.0$ & potato (sweet) & $2.0-3.0$ \\
\hline celery & $1.5-2.0$ & pumpkin & $3.0-4.0$ \\
\hline chard & $2.0-3.0$ & radish & $1.0-1.5$ \\
\hline cilantro (coriander) & $1.5-2.0$ & spinach & $1.5-2.0$ \\
\hline corn (sweet) & $3.0-4.0$ & $\begin{array}{l}\text { spinach (baby and } \\
\text { teen) }\end{array}$ & $1.0-1.5$ \\
\hline cucumber & $1.5-2.0$ & squash (summer) & $2.0-3.0$ \\
\hline eggplant & $2.0-3.0$ & squash (winter) & $2.5-3.5$ \\
\hline garlic & $1.5-2.0$ & tomato (fresh) & $2.0-4.0$ \\
\hline kale & $2.0-3.0$ & tomato (processing) & $3.0-5.0$ \\
\hline leek & $1.5-2.0$ & turnip (white) & $1.5-2.5$ \\
\hline lettuce (baby) & $1.0-1.5$ & watermelon & $2.0-3.0$ \\
\hline lettuce (iceberg) & $1.5-2.0$ & & \\
\hline
\end{tabular}

Sources: Natural Resources Conservation Service 2016; Shock et al. 2007; personal communication by growers, consultants, and farm advisors with M. Cahn. 
Example: How much soil moisture is available to an iceberg lettuce crop planted in clay loam soil?

Available moisture for a clay loam soil is approximately 0.14 inches per inch of soil depth. The allowable depletion of available soil moisture for lettuce is 30 percent, and roots of a typical lettuce crop reach a depth of 24 inches ( 2 feet) by maturity.

Available soil moisture $=$ 0.14 inches per inch of soil $\times 30 \% \div$ $100 \% \times 24$ inches $=1.0$ inch

Precipitation and Shallow Water Tables Other sources of water that can contribute to crop ET include rainfall, fog, and shallow water tables. Rainfall can be significant during the winter, early spring, or late fall in some regions of the state but is difficult to predict. Longterm rainfall records, available from CIMIS and other agencies, can be used to give a general sense of how much rain is typical, but using a conservative estimate is recommended. Near the coast, fog often contributes precipitation to crops during the summer. Amounts are usually less than a few tenths of an inch per year in most regions of the coast. Water from perched or shallow water tables can move upward into the root zone of a crop. The amount of water contributed from a shallow water table is difficult to assess, but may depend on the soil type, rooting pattern of the crop, and when the water table is present during the crop cycle. If the water table is more than 2 feet below the rooting zone, its moisture contribution is probably negligible.

\section{Determining the Overall Irrigation Water Requirement}

The overall irrigation requirement for a crop conforming to the above examples can be estimated by summing the preseason and in-season water needs and subtracting nonirrigation water sources:

\begin{tabular}{|l|c|}
\hline Crop water needs & inch \\
\hline Preseason water & 1.7 \\
\hline In-season water & \\
\hline Water for establishment & 2.4 \\
\hline ETc, leaching, DU & 14.3 \\
\hline Temperature and humidity & 0.0 \\
\hline Total & $\mathbf{1 8 . 4}$ \\
\hline
\end{tabular}

\begin{tabular}{|l|c|}
\hline Nonirrigation water sources & inch \\
\hline Change in available soil moisture & 1.0 \\
\hline Rainfall & 1.0 \\
\hline Fog & 0.1 \\
\hline Shallow ground water & 0.0 \\
\hline Total & $\mathbf{2 . 1}$ \\
\hline
\end{tabular}

\begin{tabular}{|l|c|}
\hline Irrigation water requirement & inch \\
\hline Crop water needs & 18.4 \\
\hline Nonirrigation water sources & 2.1 \\
\hline Irrigation water needed & $\mathbf{1 6 . 3}$ \\
\hline
\end{tabular}

Determining How Much Water Will Be Available for Irrigation In addition to estimating the crop water requirements, one needs an estimate of the amount of water available for irrigating during the upcoming season in order to calculate the number of acres that can be farmed. Water availability will depend on the source of the water, water rights, and local and state regulations. Water districts that are allocated surface water may not know their final water allotment until late in the spring, when most of the precipitation for the season has occurred. In this case, it may be most useful to estimate 
the land that can be planted for a range of water allocation scenarios (allocations of $20 \%, 30 \%, 40 \%, 50 \%$, and so on).

Growers who rely on groundwater for irrigation should conduct a pump test to determine how much water their wells can produce. If aquifer levels have declined during a drought, wells will likely produce less water. A pump test will determine the flow rate (gallons per minute, or gpm) that a well can produce at different output pressures. If high-pressure sprinklers are used for irrigation, a pump has a lower output flow rate than if drip tape, which requires less pressure, is used.

\section{Calculating the Total Acres That Can Be Irrigated}

The maximum acres that can be irrigated are determined by dividing the total available water by the water requirement of the crop. For example, if a grower is allocated 500 acre-feet of water, for the above example he or she can farm 368 acres of lettuce:

\section{Cropped area $=500$ acre- $\mathrm{ft} \times 12$ inches $/ \mathrm{ft} \div 16.3$ inches}

\section{Cropped area $=368$ acres}

\section{Allowances for Peak ET}

In addition to calculating the area that can be irrigated using the total amount of water available for the season, one should also calculate the area that can be irrigated based on the amount of water available per day during the period when the crop has the greatest evapotranspiration requirement. Historical CIMIS ET data can provide maximum values for reference ET during the growing season. The maximum crop coefficient value, which should range from 0.8 to 1.15 , depending on the crop, should be used to calculate the peak ET requirement. Maximum crop coefficient values for vegetable, agronomic, and tree crops are summarized in Allen et al. (1998) and in Hanson et al. (2004).

Example: How many acres can be cropped if a ranch has 2 wells with a combined output of $1500 \mathrm{gpm}$, and the peak crop ET is expected to be 0.28 inches/day in the summer? Assuming that the wells can be operated 24 hours per day:
Cropped area $=1500$ gpm $\times 24$ hours $\div 0.28$ inches $\times 453$

Cropped area $=284$ acres

where 453 is a combined constant for converting gallons to acre-inches and hours to minutes.

\section{Summary}

Under drought conditions, or when water supplies are limited, estimating the water requirement of crops is necessary to avoid planting more land than can be irrigated. Both preseason and in-season water requirements should be estimated. The major in-season crop water needs are for stand establishment, evapotranspiration, and managing salinity through leaching. The preseason water needs are mainly for leaching salts that may have built up in the soil from previous crops and for providing optimal moisture for tillage operations. Nonirrigation sources of water, such as precipitation and changes in stored soil moisture, can be subtracted from the overall irrigation requirements of the crop. Dividing the total amount of water available for irrigation by the crop water requirement provides an estimate of the total acres that can be productively farmed. 


\section{References}

Allen, R., L. Pereira, D. Raes, and M. Smith. 1998. Crop evapotranspiration-guidelines for computing crop water requirements. FAO irrigation and drainage paper 56. Rome: Food and Agriculture Organization of the United Nations.

Cahn, M., and K. Bali. 2015. Drought tip: Managing salts by leaching. Oakland: University of California Division of Agriculture and Natural Resources Publication 8550. https:// anrcatalog.ucanr.edu/pdf/8550.pdf.

Hanson, B. 2000. Irrigation pumping plants. Oakland: Division of Agriculture and Natural Resources Publication 3377. pp. 126 https://anrcatalog.ucanr.edu/Details.aspx?itemNo=3377.

Hanson, B., L. Schwankl, and A. Fulton. 2004. Scheduling irrigations: When and how much water to apply. Oakland: Division of Agriculture and Natural Resources Publication 3396. https://anrcatalog.ucanr.edu/Details.aspx?itemNo=9023.

Natural Resources Conservation Service. 2016. Sprinkler irrigation. National Engineering Handbook, Part 623, Chapter 11. https://directives.sc.egov.usda.gov/OpenNonWebContent. aspx? content $=39754$. wba.

Shock, C., A. Pereira, B. Hanson, and M. Cahn. 2007. Vegetable irrigation. In: R. Lascano and R. Sojka, eds., Irrigation of Agricultural Crops, second edition. Madison, Wisconsin: American Society of Agronomy.
To order or obtain ANR publications and other products, visit the ANR Communication Services online catalog at http://anrcatalog.ucanr.edu/ or phone 1-800-994-8849. Direct inquiries to

\section{University of California}

Agriculture and Natural Resources

Communication Services

2801 Second Street

Davis, CA 95618

Telephone 1-800-994-8849

E-mail: anrcatalog@ucanr.edu

(92019 The Regents of the University of California. This work is licensed under the Creative

Commons Attribution-NonCommercial-NoDerivatives 4.0 International License. To view a copy of this license, visit http://creativecommons.org/licenses/by-nc-nd/4.0/ or send a letter to Creative Commons, PO Box 1866, Mountain View, CA 94042, USA.

Publication 8632

ISBN-13: 978-1-62711-072-3

Drought Tip 92-03

The University of California, Division of Agriculture and Natural Resources (UC ANR) prohibits discrimination against or harassment of any person in any of its programs or activities on the basis of race, color, national origin, religion, sex, gender, gender expression, gender identity, pregnancy (which includes pregnancy, childbirth, and medical conditions related to pregnancy or childbirth), physical or mental disability, medical condition (cancer-related or genetic characteristics), genetic information (including family medical history), ancestry, marital status, age, sexual orientation, citizenship, status as a protected veteran or service in the uniformed services (as defined by the Uniformed Services Employment and Reemployment Rights Act of 1994 [USERRA]), as well as state military and naval service.

UC ANR policy prohibits retaliation against any employee or person in any of its programs or activities for bringing a complaint of discrimination or harassment. UC ANR policy also prohibits retaliation against a person who assists someone with a complaint of discrimination or harassment, or participates in any manner in an investigation or resolution of a complaint of discrimination or harassment. Retaliation includes threats, intimidation, reprisals, and/or adverse actions related to any of its programs or activities.

UC ANR is an Equal Opportunity/Affirmative Action Employer. All qualified applicants wil receive consideration for employment and/or participation in any of its programs or activities without regard to race, color, religion, sex, national origin, disability, age or protected veteran status.

University policy is intended to be consistent with the provisions of applicable State and Federal laws.

Inquiries regarding the University's equal employment opportunity policies may be directed to: Affirmative Action Contact and Title IX Officer, University of California, Agriculture and Natura Resources, 2801 Second Street, Davis, CA 95618, (530) 750-1397. Email: titleixdiscrimination@ ucanr.edu. Website: http://ucanr.edu/sites/anrstaff/Diversity/Affirmative_Action/.

An electronic copy of this publication can be found at the ANR Communication Services catalog website, http://anrcatalog.ucanr.edu/

UC This publication has been anonymously peer reviewed for technical accuracy by University of California scientists and other qualified professionals. This review REVIEWED process was managed by ANR Associate Editor for Land, Air, and Water Sciences Anthony O'Geen.

web-8/18-LC/DES/SO 